\title{
Journal of Educational
}

\section{Technology\&Online Learning}

Volume 4 | Issue $2 \mid 2021$

http://dergipark.org.tr/jetol

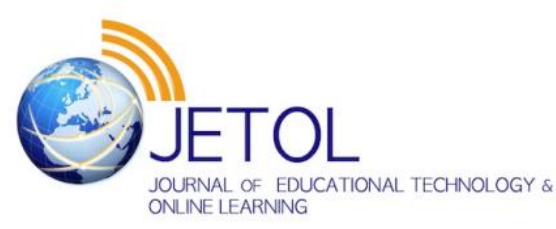

\section{The effectiveness of emotional motivational feedback messages via online assignments in information technologies and software course academic achievement}

\author{
Yağmur Demir ${ }^{\mathrm{a}}$ D, Fırat Sarsar ${ }^{\mathrm{b} *}$ \\ ${ }^{\text {a }}$ Ministry of National Education, Turkey. \\ ${ }^{\mathrm{b}}$ Ege University, Turkey.
}

Suggested citation: Demir, Y. \& Sarsar, F. (2021). The effectiveness of emotional motivational feedback messages via online assignments in information technologies and software course academic achievement. Journal of Educational Technology \& Online Learning, 4(2), $280-292$.

\begin{tabular}{ll}
\hline Article Info & Abstract \\
\cline { 2 - 3 } $\begin{array}{l}\text { Keywords: } \\
\text { Emotion }\end{array}$ & $\begin{array}{l}\text { The aim of this study was to determine the effect of emotional motivational feedback } \\
\text { Feedback }\end{array}$ \\
Motivational Feedback & $\begin{array}{l}\text { scope of Information Technologies and Software course on academic success. The } \\
\text { research was quantitatively designed based on quasi-experimental design with pretest- } \\
\text { Emotional Motivational }\end{array}$ \\
peedback & $\begin{array}{l}\text { a statest control group. Participants of the study were } 57 \text { sixth grade students studying at } \\
\text { were given the students in the experimental group and only motivational feedback was } \\
\text { given the students in the control group. The data were collected through the academic }\end{array}$ \\
achievement test developed by Öztürk (2015) within the scope of Information \\
Technologies Course. The data obtained from the pretests and posttests applied were \\
analyzed by paired group t-test and independent groups t-test, and comparisons were \\
made. In the light of the findings obtained, it was seen that the increase in the posttest \\
scores of both groups was significant, but that the increase in the scores between the \\
groups did not differ significantly.
\end{tabular}

\section{Introduction}

Students interact with each other in cognitive, social and emotional ways in the learning environments (Spanoudis and Kyza, 2009). The interaction are realted to motivation in education process (Şener, Ertem \& Meç, 2020; Meşe \& Sevilen, 2021). It is known that many variables affect education, and that the education process is a multi-dimensional process. Feedback is one of the leading variables among these and has become the center of many approaches in education in the process. The importance of feedback is also emphasized in instructional designs based on different educational philosophies (Mory, 2004). Through feedback, teachers realize how their students have understood the concepts and how much they have learned (Connellan, 2002). Giving feedback, which is accepted as responses to students' behavior, tasks, and homework, is a very important technique for learning (Sprenger, 2005). Although feedback can be effective on students in many aspects such as learning, motivation and emotion, it is known that students' reactions to feedback are generally emotional (Burke and Pieterick, 2010). Emotions are very important factors in

\footnotetext{
* Corresponding author. Ege University, Turkey

e-mail adresses: firat.sarsar@ege.edu.tr
} 
learning that affect students' success and motivation (Schutz and Pekrun, 2007). Emotions also provide clues to educators about what happens during the lesson in the classroom (Meyer and Turner, 2006).

ARCS Motivation Model is a motivational design model based on an expectation-value theory that suggests that an individual is motivated when personal needs and positive outcome expectations arising from tasks are met (Chyung, 2008). This model has specific strategies that must be followed when designing an instruction, and progresses step by step (Visser and Keller, 1990). It is important to include the categories of this model dating back to 1979 in an efficient motivational message design (Visser and Keller, 1990). The ARCS Motivation Model is a model consisting of the initials of Attention, Relevance, Confidence and Satisfaction, and in these categories, the conditions necessary for the motivation of the individual are included (Keller, 2000). Successfully tested in terms of reliability and validity in more than twenty countries and in a variety of contexts, including traditional teaching, this model is used by many researchers for its ease of application and effectiveness (Gabrielle, 2003). According to this model, learners are motivated if they believe that they will be successful and if they see the learning process as valuable (Balantekin and Bilgin, 2017). Motivational feedback in the research were given based on this model.

Motivational feedback is based on informing the students on how well they are doing their task and encouraging them, and it should enable students to learn not only cognitively and socially, but also emotionally (Kulhavy and Wager, 1993; Sarsar, 2014). Emotional motivational feedback was developed by Sarsar (2014) as a result of the difficulties experienced in giving emotional and motivational feedback in text-based environments. The emotional motivational feedback message is to give a feedback message which includes both motivational strategies and emotional content for increasing the students' motivation and encoruging them them to learn more about a specific topic. The main difference that distinguishes emotional motivational feedback messages from other feedback messages is that they include strategies such as using different font styles and formatting, emojis, and semantic values of words to increase the effects of emotion (Sarsar, 2014). There are various methods such as using the semantic value of words in order to apply emotional content, underlining capital letters, providing effects for scripts, using expressions and punctuation marks ( Great!) (Sarsar, 2008; Sarsar and Kışla, 2013). Although the word "so" and the word "soooooo" seem to have the same meaning, the word "soooooo" creates quite a different emotional impact on the student (Sarsar and Ceylan, 2018). It is stated that font styles and writing words in bold, italic or color contribute to emotional content (Sarsar, 2014). Although emojis do not have the same effect on every student, it is emphasized that the use of the most frequently used emojis such as happy, very happy, sad, pleasant, angry, confused is important in adding emotional content to the feedback (Sarsar, 2008).

Giving feedback in online environment is quite different from giving feedback in face-to-face environment. Feedback given in face-to-face environment can be written or oral. The gestures and mimics of the people who give feedback in the oral feedback given in this environment are also important elements in feedback. The importance of adding emotion to feedback is once again evident at this point. All of these directly affect motivation. The need to add emotion to the feedback given to students in online environment has emerged at this point, and the ARCS model developed by Keller has been used for years as the best motivational teaching design model. Based on this model, Sarsar (2014) enabled emotions and feedback to come together in online environment by adding emotional content to messages. The emotional motivational feedback (EMF) type was first developed by Sarsar (2014). EMF, developed by Sarsar (2014), is a type of motivational feedback message that adds emotional content that involving the semantic value of words, formatting techniques and expressions. Emotional motivational feedback messages are based on using the ARCS Model and emotional content strategies.

Sarsar (2014) found that the EMF messages he used in his study both increased students' attitudes towards the lesson in a positive way, and the students stated that they liked these messages. Sarsar and Ceylan 
(2017) carried out a qualitative study in Turkey with the participation of university students on emotional motivational feedback type, and they concluded EMF messages were more effective than motivational feedback (MF) messages. The important point in emotional motivational feedback is the provision of motivation that can rendered more effective by using positive feedback and verbal praise, as stated by Deci (1971). Another important point in emotional motivational feedback is the emotion that affects motivation by using feedback (Burke and Pieterick, 2010). In this research, two powerful variables called emotion and motivation in feedback were investigated, and the focus was placed on the combination of three factors: feedback, emotion, and motivation.

When the studies conducted on feedback are examined, the importance of feedback in increasing student achievement is encountered frequently (Burnett, 2002; Büyükbay, 2007; Çetin, 2015; Demirci, 2010; DiGennaro et al., 2007; Dökmen, 1982; Eraz, 2014; Oğuz, 1994). It was observed that students and teachers had similar views on the use of feedback, and that teachers' opinions about feedback did not differ according to their gender, professional seniority, class size and socio-economic status. It was concluded that the most effective type was seen as video in the study in which feedback types covering different multimedia were used (Ayar, 2009). In the study comparing the effectiveness of peer and teacher feedback types, it was observed that students preferred teacher feedback. In another study, the effectiveness of peer feedback was the subject of research, and it was observed that it significantly increased student achievement (Can, 2019; Kilıç, 2019).

The type of feedback given by the teacher might change the success goals and motivations of the students. It is also important that teachers should know the different types of feedback for giving them in a right way. In the literature review, it was seen that the most used feedback type by classroom teachers was reinforcing, and the least type used was motivational feedback. (Demir, 2013; Demirci, 2010; Dökmen, 1982; Erturan, 2014) .

Another study shows that students who receive positive feedback get higher scores in learning-oriented environments compared to students who receive negative feedback, and lower scores in performanceoriented learning environments (Dökmen, 1982; Viciana and Cervelló, 2007). In studies conducted on university students, it is emphasized that task feedback is the most effective type (Demir, 2013; Erturan, 2014; Viciana and Cervelló, 2007; Voerman et al., 2012; Wilbert et al., 2010).

When the literature is examined, it is seen that there is a lot of research on feedback, but that the number of studies conducted on the effect of emotional motivational feedback messages is limited. In the studies examining the efficiency of the systems designed on the basis of the ARCS Motivation Model, it was found that the attractiveness of teaching was high, the needs of the students were met, a desire for success was created, and these systems helped learners to be satisfied with teaching teaching (Eraz, 2014; Pirker, Riffnaller-Schiefer \& Gült, 2014; Sarsar, 2014).

\subsection{The Purpose of the study}

The aim of this study was to examine the effect of emotional motivational feedback messages given to the online assignments of the 6th grade students taking the Information Technology and Software course on the academic achievement of the students. In this study, different components were used, including Visser and Keller's (1990) motivational message design, ARCS Model, and emotional content strategies (Sarsar, 2014) in order to understand the effectiveness of emotional motivational messages based on feedback strategies. In the research, the emotional motivational feedback message was operationally defined as a feedback message that includes motivational strategies and emotional content to encourage and motivate students to learn more and focus on a particular topic, while the motivational feedback message was defined 
as a feedback message that includes motivational strategies to encourage and motivate students to learn more and focus on a specific subject. The research focused separately on the use of emotion in motivational feedback and motivation independent of emotional content, because the subject of the research was to determine how students would be more successful when their motivation for completing a task was increased in what way.

\subsection{Research questions}

Within the scope of the research, answers to the following questions were sought:

Do the pretest and posttest scores of the groups that received motivational feedback differ significantly?

Do the pretest and posttest scores of the groups receiving emotional motivational feedback differ significantly?

Does the increase in the posttest scores of the groups that received emotional motivational feedback and the groups that only received motivational feedback differ significantly?

\section{Methodology}

This study, which examined the effect of emotional motivational feedback given to sixth grade students on their academic achievement, is a quantitative study designed on the basis of quasi-experimental design with pretest-posttest control groups. An experimental group and a control group were included in the study. The dependent variable of the study was the academic success of the groups determined in the teaching of "Microsoft Office PowerPoint" software in the Information Technologies course curriculum. The types of motivational and emotional motivational feedback given for online environment assignments were considered as the independent variable in the study.

\subsection{Participants}

The study group consisted of 57 sixth grade students studying at a state secondary school in the one of districts of Izmir, Turkey. The demographic information about the study group is given in Table 1.

Table 1.

Students' Distribution by Class, Grade Level and Gender.

\begin{tabular}{|c|c|c|c|c|c|}
\hline \multirow[b]{3}{*}{ Number of Students } & \multicolumn{2}{|c|}{ Experimental Group } & \multicolumn{2}{|c|}{ Control Group } & \multirow[b]{2}{*}{ Total } \\
\hline & Female & Male & Female & Male & \\
\hline & 13 & 15 & 15 & 14 & 57 \\
\hline
\end{tabular}

As it can be seen in Table 1, while two randomly selected sixth grade classes $(6 \mathrm{~A} / \mathrm{B})$ out of the existing sixth grade classes constituted the experimental group of 28 students, the other two classes (6C/D) constituted the control group of 29 students. While the experimental group provided with EMF consisted of 13 female students and 15 male students, the control group given MF consisted of 15 female and 14 male students. 


\subsection{Data Collecting Tools}

The research data were collected through the academic achievement test developed by Öztürk (2015) within the scope of Information Technologies course. Pretest and posttest consisting of 10 questions were administered to the students at the beginning and end of the study. It was determined that the validity and reliability studies of both tests were performed.

\subsection{Application Process}

The study duration was six weeks. After the pretest was administered to both groups, the teaching phase was started. Following the face-to-face lessons in the classroom environment, online homework was given to all groups via e-mail. Emotional motivational feedback was given during the research about the experimental group's homework in the online environment, and only motivational feedback was given to the homework of the control group.

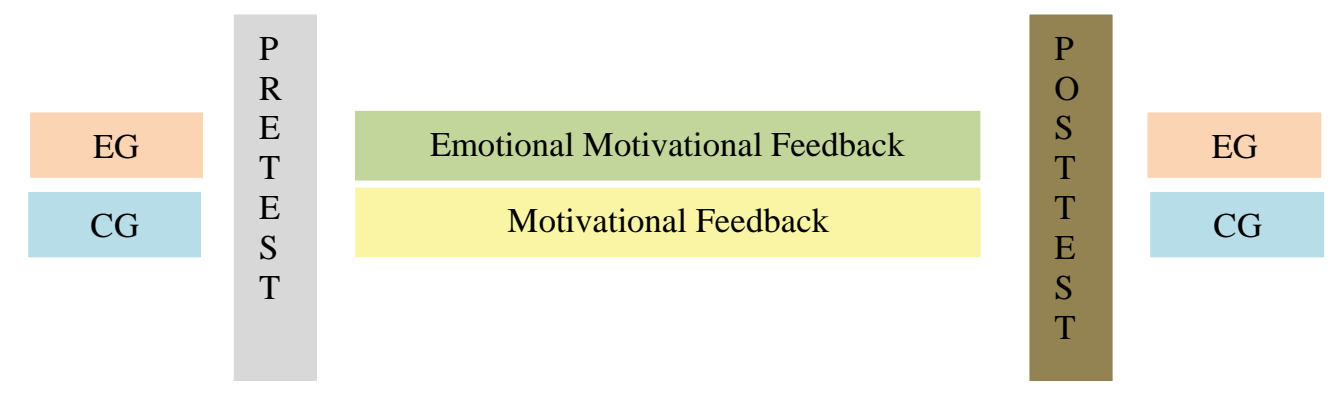

EG: Experimental Group and CG: Control Group

Fig. 1. Application Process.

As seen in Figure I, pretest was applied in the first week and posttest was applied in the sixth week of the application process. During the weeks when the outcomes were taught, homework was given to the students via e-mail, and their assignments were evaluated by sending motivational feedback to the students in the control group and emotional/ motivational feedback to the students in the experimental group. A schedule was prepared for the feedback to be given to students, and the scoring was determined in advance. While preparing the scoring table, the opinion of Sarsar (2014), who had previously worked on this subject, was taken, and it was decided that it would be appropriate to have a certain standard in scoring. All feedback on students' homework was given online.

\subsection{Data Analysis}

In the study, the missing pre-post tests' results of 3 subjects were excluded. The inclusive students who got zero in the pretest and the posttest were also tested so that they would not feel bad while their friends were doing the test, but these students were not included in the study. Also, one student participated in the pretest and did not show up for the posttest.

After the data were checked for usability, they were transferred to the computer, and all necessary calculations for the analysis were made using a statistics package program. Paired groups t-test and independent groups t-test techniques were used to analyze the data. The level of significance in the interpretation of statistical results was taken as.01. 


\subsection{Validity and Reliability}

When the difficulty and discrimination levels of the academic pretest were examined, it was seen that the average difficulty was 0.56 , and the average discrimination was 0.66 . It was observed that the average difficulty of the academic achievement posttest was 0.54 , and the average discrimination was 0.7 . When these values are examined, it is seen that the average difficulty and discrimination values of both tests are appropriate.

\subsection{Research Procedures}

The researcher carried out a 6-week study with students at a state-owned secondary school after obtaining the necessary permissions

\section{Findings and Discussions}

\subsection{The Effect of Motivational Feedback on Academic Achievement}

Paired groups t-test was used in order to find the answer to the question "Do the pretest and posttest scores of the groups that received motivational feedback differ significantly?" In order to perform this test, the normal distribution assumption was tested first. Findings regarding the obtained results are given in Table 2.

Table 2.

Kurtosis and Skewness Values Belonging to the Group Provided Motivational Feedback.

\begin{tabular}{lllll}
\hline & \multicolumn{2}{c}{ Skewness } & \multicolumn{2}{c}{ Kurtosis } \\
\hline & Statistic & Standart Error & Statistic & Standart Error \\
Pretest & .93 & .44 & .82 & .86 \\
PostTest & .72 & .44 & 1.69 & .86 \\
\hline
\end{tabular}

As seen in Table 2, the assumption of normal distribution was not provided. The skewness / standard error and kurtosis / standard error values between +1.96 and -1.96 indicate that the normal distribution assumption is achieved (Field, 2005). In order to provide this assumption, square root transformation was applied. The findings obtained as a result of the square root transformation are presented in Table 3.

Table 3.

Kurtosis and Skewness Values Belonging to the Group Given Motivational Feedback After the Square Root Transformation.

\begin{tabular}{lllll}
\hline & \multicolumn{2}{c}{ Skewness } & \multicolumn{2}{c}{ Kurtosis } \\
\hline & Statistic & Standart Error & Statistic & Standart Error \\
Pretest & .30 & .44 & .02 & .86 \\
PostTest & .11 & .44 & 1.56 & .86 \\
\hline
\end{tabular}

When Table 3 was examined, it was seen that the data after square root transformation provided the normal distribution assumption. After this stage, paired groups t-test was performed in order to determine the findings for the first sub-problem. 


\section{Table 4.}

Paired Groups T-Test Results of the Group Provided with Motivational Feedback.

\begin{tabular}{lllllll}
\hline & N & $\overline{\mathbf{X}}$ & S & sd & t & P \\
\hline Pretest & 28 & 5.54 & 1.36 & 27 & -5.24 & .00 \\
PostTest & 28 & 6.70 & .89 & & & \\
\hline
\end{tabular}

When Table 4 is examined, it is seen that the pretest and posttest scores of the students in the control group differed significantly in terms of the answer to the first problem of the study $(\mathrm{t}=-5.24, \mathrm{p}<.01)$. It was observed that while pretest mean score of the students was $\bar{X}=5.54$, after the motivational feedback was provided, the mean score went up to $\bar{X}=6.70$. All scores given here are the findings obtained after the square root transformation.

\subsubsection{The Effect of Emotional motivational Feedback on Academic Achievement}

In order to find an answer to the question "Do the pretest and posttest scores of the groups receiving emotional motivational feedback differ significantly?", which is the second problem of the study, it was first examined whether the academic achievement pretest and posttest scores of the study group showed a normal distribution.

Table 5.

Descriptive Statistics Results Regarding the Control Group Students.

\begin{tabular}{lllll}
\hline & \multicolumn{2}{c}{ Skewness } & \multicolumn{2}{c}{ Kurtosis } \\
\hline & Statistic & Standart Error & Statistic & Standart Error \\
Pretest & -.24 & .43 & -.74 & .84 \\
PostTest & .08 & .43 & -1.07 & .84 \\
\hline
\end{tabular}

As seen in Table 5, it was observed that the normal distribution assumption was achieved as a result of the analysis performed. The skewness / standard error and kurtosis / standard error values between +1.96 and -1.96 indicate that the normal distribution assumption is achieved (Field, 2005).

Table 6.

Paired Groups T-Test Results of the Group Provided with Emotional Motivational Feedback.

\begin{tabular}{lllllll}
\hline & N & $\overline{\mathbf{X}}$ & S & Sd & t & P \\
\hline Pretest & 29 & 41.72 & 17.44 & 28 & -5.46 & .00 \\
PostTest & 29 & 54.48 & 12.35 & & & \\
\hline
\end{tabular}

When Table 6 is examined, it is seen that the pretest and posttest scores of the students in the experimental group differ significantly in terms of the answer to the second problem of the study $(t=-5.46, p<.01)$. It was observed that while the pretest mean score of the students was $\bar{X}=41.72$, after the emotional motivational feedback was given, the score increased to $\overline{\mathrm{X}}=54.48$.

\subsubsection{The Effect of Motivational Feedback and Emotional motivational Feedback on Academic Achievement}

In order to find the answer to the question "Does the increase in the posttest scores of the groups that received emotional motivational feedback and the groups that only received motivational feedback differ significantly?", which is the third problem of the research, it was examined whether the increase in the 
posttest mean scores of these two different groups displayed a normal distribution or not. For this, first of all, improvement score was obtained for each student. This score was obtained by subtracting the pretest score from the posttest score of each student. In the first analyses, a normal distribution was not observed, and square root transformation was performed.

Table 7.

Kurtosis and Skewness Values Related to the Improvement Score.

\begin{tabular}{lllll}
\hline & \multicolumn{3}{c}{ Skewness } & Kurtosis \\
\hline Improvement & Statistic & Standart Error & Statistic & Standart Error \\
Score & 1.26 & .32 & 3.84 & .62 \\
\hline
\end{tabular}

As seen in Table 7, the assumption of normal distribution was not provided. In order to provide this assumption, square root transformation has been made. Findings obtained as a result of square root transformation are presented in Table 8.

Table 8.

Kurtosis and Skewness Values Regarding Improvement Score After Square Root Transformation.

\begin{tabular}{lllll}
\hline & \multicolumn{3}{c}{ Skewness } & Kurtosis \\
\hline Improvement & Statistic & Standart Error & Statistic & Standart Error \\
Score & .72 & .32 & 1.00 & .63 \\
\hline
\end{tabular}

As seen in Table 8 , it was observed that the normal distribution number was achieved after the square root transformation. The skewness / standard error and Kurtosis / standard error values between +1.96 and -1.96 indicate that the normal distribution number is achieved.

Table 9.

MF and EMF Independent Groups T-Test Results of the Two Groups.

\begin{tabular}{lcccccc}
\hline & $\mathbf{N}$ & $\overline{\mathbf{X}}$ & $\mathbf{S}$ & $\mathbf{S d}$ & $\mathbf{t}$ & $\mathbf{P}$ \\
\hline Control Group & 28 & 3.50 & 1.57 & 54 & .63 & .53 \\
$\begin{array}{l}\text { Experimental } \\
\text { Group }\end{array}$ & 29 & 3.24 & 1.53 & & & \\
\hline
\end{tabular}

According to the independent groups t-test results indicated in Table 9, it was observed that there was a difference between the posttest score increases of the groups, but this difference was not significant. All scores given here are the findings obtained after the square root transformation. As can be seen from the results in the table, it was concluded that there was no significant difference in terms of academic achievement between the use of two different types of feedback.

\section{Conclusion and Suggestions}

In the study, it was concluded that there was a significant difference between the academic achievement pretest and posttest scores of the control group, who were given motivational feedback messages for the Information Technologies course online homework. According to this result, it can be said that motivational feedback messages are effective in increasing academic achievement levels. Therefore, motivational feedback messages should be emphasized for a more effective Information Technology education. 
Another result obtained from the study was that there was a significant difference between the academic achievement pretest and posttest scores of the experimental group to whom emotional motivational feedback messages were given for the Information Technologies course online homework. According to these results, it can be said that emotional motivational feedback messages have an important effect in increasing academic achievement levels, and that emotional motivational feedback messages should be taken into consideration for a more effective Information Technology education.

In this current study, in which the effects of motivational and emotional motivational feedback messages on students' academic achievement were compared. It was concluded that the effect of two different types of feedback on achievement was significant, but there was no significant difference between the groups in terms of academic achievement. In many studies, it has frequently been proven that the effect of feedback on learning is significant (Ezzat et al., 2017). In this study, in which the effect of feedback on success was revealed once again, it was seen that adding emotional content to messages did not yield a different result in achievement score. This also shows that it can be concluded that motivational and emotional/ motivational feedback messages create the same effect on students.

As noted earlier, giving feedback in online environment is quite different from giving feedback in face-toface environment. Feedback given in a face-to-face environment can be written or oral, and the gestures and mimics of the people who give oral feedback can also affect the feedback. Thus, the importance of adding emotions to feedback is once again understood at this point. It is also known that all these directly affect motivation. The need to add emotion to the feedback given to students in online environment has emerged at this point, and the ARCS model developed by Keller has been used for years as the best motivational teaching design model. With the addition of emotional content to the messages by Sarsar (2014) based on this model, emotions and feedback were brought together in online environment. As seen in the research results, when motivational or emotional motivational feedback was given to students, students' achievement increased no matter what type of feedback was provided. It is thought that when this study, which covered 6th grade students in the 12-14 age group, is carried out on different age groups, emotional content may be more effective depending on the age.

In the literature review conducted, it was seen that the emotional motivational feedback type was developed by Sarsar (2014) for the first time, and Sarsar found that this type of message used in his research increased both the attitude of the students to the lesson positively, and the students expressed that they liked these messages with emotional content. In the qualitative research they conducted on emotional motivational feedback type in Turkey with the participation of university students, Sarsar and Ceylan (2017) concluded emotional motivational messages were more effective than motivational messages. When the research results are evaluated in this direction, it is seen that there is no study in the literature comparing the effects of these two types of feedback on achievement, and that in this study, the two types of feedback had the same effect on learning. In a future qualitative study on this topic with students of the same age group, it is predicted that students will find emotional motivational feedback messages more positive, as university students did. The result of a study that will measure achievement in two different types of feedback in university students is a matter of curiosity.

Feedback differs according to many variables. For this reason, how and in which environment the feedback is given is as important as when and to whom it is provided (Sarsar, 2018). Since the type of feedback given in this study was provided in a text-based environment, it would not be possible to give feedback immediately in such a learning environment. The homework sent by the students via e-mail was scored, and a feedback message was sent in the same week before the next class time came. It is thought that different results may be encountered when questions are asked in an online chat environment or in a simultaneous learning environment and motivational or emotional motivational feedback is given to 
students immediately. In the study, the importance of the necessity of shaping emotional and motivational messages used in text-based learning environments on the basis of these variables was revealed.

Sixth grade students studying at state schools were selected as the study group. Research is recommended on different grade levels and in different school types. The research covered a total of six weeks, including the weeks when pretest and posttest were administered. It is thought that the effectiveness of feedback types may become more evident in a study where the research period is kept longer.

Since it is observed that students may have difficulties in using e-mail, it is thought that additional training should definitely be given on this subject one week prior to the research. This research is limited to the Information Technology course outcomes. Practitioners can develop sample applications for other outcomes using the method adopted in the research.

The research conducted within the scope of this study includes a small-scale experimental group of 57 students in a limited time. It is thought that the success graph of the obtained data may differ by applying the said research on a larger sample. The research was limited to a six-week period. If it is extended over a longer period of time and supported with more feedback, there may be differences in the increase in achievement scores between groups. In addition, the research covered sixth grade students. Similar studies can be conducted on other grade levels in new studies. The effectiveness of emotional motivational feedback according to gender was not examined in the study; therefore, new research can also be considered in this respect.

\section{References}

Ayar, T. (2009). Öğretme-öğrenme sürecinde geri bildirim: Dördüncü ve beşinci sınıf öğretmen ve öğrencilerinin görüsslerine gore sınıfta geri bildirim kullanımının değerlendirilmesi. Yayınlanmamış Yüksek Lisans Tezi, Çukurova Üniversitesi, Eğitim Bilimleri Enstitüsü, Adana.

Balantekin, Y., \&Bilgin, A. (2017). ARCS Motivasyon Modeli'nin öğrencilerinin motivasyonlarına, tutumlarına ve akademik başarılarına etkisi. İlkögretim Online, 16(1): 161-177.

Burke, D., \&Pieterick, J. (2010). Giving students effective written feedback. McGraw-Hill Education (UK).

Burnett, P. C. (2002). Teacher praise and feedback and students' perceptions of the classroom environment. Educational psychology, 22(1), 5-16.

Büyükbay, S. (2007). The Effectiveness of Repetition As Corrective Feedback. Yayımlanmamış Yüksek Lisans Tezi, Bilkent Üniversitesi Yabanc1 Dil Olarak İngilizce Öğretimi Bölümü, Ankara.

Can, E. (2019). Yazılı Akran Dönüt Verme Eğitiminin Yabancı Dil Olarak İngilizce Öğrenen Türk Öğrencilerin Verdiği Dönütün Türüne ve Yazma Becerilerinin Gelişimine Etkisi. Anadolu Üniversitesi, Eğitim Bilimleri Enstitüsü, Şubat 2019.

Chyung, S. Y. (2008). Foundations of instructional and performance technology. Amherst, Mass.: HRD Press.

Connellan, T. K. (2002). Bringing out the best in others! : 3 keys for business leaders, educators, and parents. Austin, TX: Bard Press. 
Çetin, M., \& Taşkın, Ç. Ş. (2015). Sözlü dönütün ilkokul öğrencilerinin akademik başarı, derse yönelik tutum ve üstbilişsel farkındalığına etkisi. Sakarya Üniversitesi Ĕ̈itim Fakültesi Dergisi, (29), 3967.

Deci,E.L.(1971).Effects of externally mediated rewards on intrinsic motivation. Journal of Personality and Social Psychology,18, 105-115.

Demir, F. (2013). Sınıf Öğretmenlerinin Kullandıkları Dönüt Türleri (Bayburt Ili Örneği).Yayınlanmamış yüksek lisans tezi, Gazi Üniversitesi Eğitim Bilimleri Enstitüsü, Ankara.

Demirci, P. (2010). The Effect of Explicit and Implicit Corrective Feedback On Intake Of Past Tense Marker. Yayımlanmamış Yüksek Lisans Tezi, Hacettepe Üniversitesi Sosyal Bilimler Yabancı Diller Eğitimi Bölümü, Ankara.

DiGennaro, F. D., Martens, B. K., \&Kleinmann, A. E. (2007). A Comparison Of Performance Feedback Procedures On Teachers'Treatment Implementation Integrity and Students'Inappropriate Behavior In Special Education Classrooms. Journal of applied Behavior analysis, 40(3), 447-461.

Dökmen, Ü. (1982). Farklı tür geri bildirimlerin öğrenmeye etkisi. Ankara Üniversitesi Eğitim Bilimleri Fakültesi Dergisi, 15 (2), 71-79.

Eraz, G. (2014). Sını öğretmenlerinin öğrencilerin ders dışı matematik etkinliklerine ilişkin uyguladıkları geribildirimlerin akademik başarl ve tutuma etkisi (Master's thesis, Adnan Menderes Üniversitesi, Sosyal Bilimler Enstitüsü).

Erturan-Ilker, G. (2014). Effects of feedback on achievement goals and perceived motivational climate in physical education.Issues in Educational Research, 24(2), 152.

Ezzat, H., Camarda, A., Cassotti, M., Agogué, M., Houdé, O., Weil, B., \& Le Masson, P. (2017). How minimal executive feedback influences creative idea generation. PLoS ONE, 12(6), 1-10. http://doi.org/10.1371/journal.pone.0180458

Field, A. (2005). Discovering statistics using SPSS. Sage Publication Ltd.

Gabrielle, D. M. (2003). The Effects of Technology-Mediated Instructional Strategies on Motivation, Performance, and Self-Directed Learning. Unpublished Doctoral Dissertation. The University of Florida, Tallahassee, FL.

Keller, J. (2000). How to integrate learner motivation planning into lesson planning: The ARCS model approach, Paper presented at VII Semanario, 1-17.

Kılıç, M. (2019). Akran Dönütü Öğretmen Dönütüne Karşı: Öğrencilerin Yazma Becerilerinde Söylem Belirleyicilerini Geliştirmek Üzerine Karşılaştırmalı Bir Vaka Çalışması. Gazi Üniversitesi.

Koçdar, S. (2006). Uzaktan Eğitim Ders Kitaplarının Geri bildirim Açısından Değerlendirilmesi: Anadolu Üniversitesi'nin Uzaktan Eğitim Veren İşletme Ve İktisat Fakülteleri Örneği.

Köğce D., Baki A., Ortaokul Matematik Öğretmenlerinin Geri bildirim Kavramı, Geri Bildirimin Veriliş Tarzı ve Zamanlaması İle İlgili İnançları /JSS 13(3) (2014):767-792 
Kulhavy, R. W., \& Wager, W. (1993). Feedback in Programmed Instruction: Historical Content and Implications for Practice. In John V. Dempsey \& G. C. Sales (Eds.), Interactive instruction and feedback. Englewood Cliffs, N.J: Educational Technology Publications.

Malik, S. (2014). Effectiveness of ARCS model of motivational design to overcome non completion rate of students in distance education. Turkish Online Journal of Distance Education, 15(2), 194-200.

Meşe, E. \& Sevilen, Ç. (2021). Factors influencing EFL students' motivation in online learning: A qualitative case study. Journal of Educational Technology and Online Learning, 4(1), 11-22.

Meyer, D. K., \& Turner, J. C. (2006). Re-conceptualizing Emotion and Motivation to Learn in Classroom Contexts. Educational Psychology Review, 18(4), 377-390. doi:10.1007/s10648-0069032-1

Mory, E. H. (2004). Feedback research revisited. Handbook of research on educational communications and technology, 745-783.

Oğuz, A. (1994). Fen öğretiminde ipuçları ve dönüt-düzeltme işlemlerinin erişi düzeyine etkisi. Ĕ̈itimveBilim, 18(94).

Öztürk, Ö. (2015). Bilgi ve İletişim Teknolojileri Entegrasyonunu Sağlamak Amaciyla Yürütülen S osyal A ğ Destekli Bilişim Teknolojileri Dersinin Etkinliğine İlişkin Bir Durum Çalışması. Doktora Tezi, Mustafa Kemal Üniversitesi, Fen Bilimleri Enstitüsü, Enformatik Anabilim Dalı, Hatay.

Pirker, J., Riffnaller-Schiefer, M., \&Gütl, C. (2014, June). Motivational active learning: engaging university students in computer science education. In Proceedings of the 2014 conference on Innovation \& technology in computer science education (pp. 297-302).

Sarsar, F. (2008). Çevrimiçi öğrenme ortamlarında işbirlikli öğrenmenin öğretmen adaylarının sosyal becerilerine etkisi. Unpublished master thesis. EgeÜniversitesi, Fen BilimleriEnstitüsü, İzmir.

Sarsar, F. (2014). The Effectiveness of Emotional Motivational Feedback Messages. (Doctoral dissertation). Georgia State University, USA.

Sarsar, F , Ceylan, B . (2017). Öğretmen Adaylarının Duygusal Motivasyonel Geri Bildirim Mesajlarına İlişkin Görüşlerinin İncelenmesi. Ege Eğitim Teknolojileri Dergisi, 1(2), 125-134.

Sarsar, F , Ceylan, B . (2018). Çevrimiçi Öğrenme Ortamlarında Duygusal Motivasyonel Geri Bildirim. H. F. Odabaşı, B. Akkoyunlu ve A. İşman (Ed). Eğitim teknolojileri okumaları 2018, (11. Bölüm, ss. 168-184). TOJET, SakaryaÜniversitesi, Adapazar1.

Sarsar, F., \&Kisla, T. (2013, March). Students' emotional transfers in online environment. In Society for Information Technology \& Teacher Education International Conference (pp. 2401-2406). Association for the Advancement of Computing in Education (AACE).

Schutz, P. A., \&Pekrun, R. (2007). Emotion in education. Amsterdam; Boston: Elsevier Academic Press.

Spanoudis, G., \&Kyza, E. A. (2009). Integrating Knowledge of Cognitive System and ELearning Applications. In C. Mourlas, N. Tsianos, \& P. Germanakos (Eds.), Cognitive and Emotional 
Processes in Web-Based Education: Integrating HumanFactors and Personalization. IGI Global. Retrieved from http://services.igiglobal. com/resolvedoi/resolve.aspx?doi=10.4018/978-1-60566$392-0$

Sprenger, M. (2005). How to teach so students remember. Alexandria, Va.: Association for Supervision and Curriculum Development. Retrieved from http://site.ebrary.com/id/10081763

Şener, B., Sağlam Ertem, İ., Meç, A., (2020). Online teaching experiences of ELT instructors. Journal of Education, Technology and Online Learning. 3(3), 340-362.

Viciana, J., Cervelló, E. M., \& Ramirez-Lechuga, J. (2007). Effect of manipulating positive and negative feedback on goal orientations, perceived motivational climate, satisfaction, task choice, perception of ability, and attitude toward physical education lessons. Perceptual and motor skills, 105(1), 6782.

Visser, J. \& Keller, J. M. (1990) The clinical use of motivational messages - an inquiry into the validity of the Arcs model of motivational design. Instructional Science, 19(6), 467-500.

Voerman, L., Meijer, P.C., Korthagen F. A. J. \& Simons, R. J. (2012). Types and Frequencies of Feedback Intervations in Secondary Education. Teaching and Teacher Education, 28: 1107-1115

Wilbert, J., Grosche, M., \& Gerdes, H. (2010). Effects of evaluative feedback on rate of learning and task motivation: an analogue experiment. Learning Disabilities: A Contemporary Journal, 8(2), 43-52. 